\title{
Fighting for King Coal's Crown: Business Actors in the US Coal and Utility Industries
}

\author{
Christian Downie*
}

\begin{abstract}
Over the last two decades, business actors have received growing attention in global environmental politics. In the context of climate change, scholars have demonstrated the capacity of business actors to directly shape outcomes at the national, international, and transnational levels. However, very little work has focused exclusively on business actors in the coal and utility industries. This is surprising, given that resistance from these industries could delay or even derail government attempts to address climate change. Accordingly, this article focuses directly on the preferences of business actors in the coal and utility industries. Drawing on interviews with executives across the US energy sector, it considers business preferences on two of the most important attempts by the Obama administration to limit emissions from coal: the Waxman-Markey bill and the Clean Power Plan. In doing so, it provides new insights about the preferences of these actors and the divisions within these industries that could be exploited by policy-makers and activists seeking to enact climate change regulations.
\end{abstract}

Over the last two decades, business actors have received growing attention in global environmental politics, for good reason. Existing scholarship has shown that business actors are critical to addressing some of the most pressing environmental problems facing the globe. In the context of climate change, scholars have demonstrated the capacity of business actors to directly shape outcomes at the national, international, and transnational levels (Falkner 2008; Meckling 2011; Newell 2000). However, very little work has focused exclusively on business actors in the coal and utility industries. To the extent that business actors in these industries have been considered, this has typically been as part of a broader coalition of business actors (see, e.g., Knox-Hayes 2012; Skjærseth et al. 2013). This is surprising, given that the coal industry, which produces coal, and the utility industry, which burns it to generate electricity, are the largest sources of global

* I am grateful to the participants who kindly agreed to be interviewed for this project, and to the editors and anonymous reviewers for their insightful comments. Sophie Adams provided excellent research assistance. 
greenhouse gas emissions. Furthermore, resistance from these industries could delay or even derail government attempts to address climate change.

Accordingly, this article focuses directly on business actors in both the coal and utility industries. Specifically, it deals with questions such as, what are the preferences of business actors in these industries toward efforts to limit emissions from coal? How are they determined? And importantly, could divisions within and between these industries be exploited by governments seeking to enact climate change regulations? This article takes up these questions by examining the role of business actors in the US coal and utility industries. Specifically, it considers business preferences regarding two of the most important attempts by the Obama administration to limit emissions from coal: the Waxman-Markey bill, an attempt to create an emissions trading system in 2009, and the Clean Power Plan, designed to limit emissions from power plants in 2014. While these initiatives have received attention in the literature (see, e.g., Skjærseth et al. 2013), few have examined the role of business across both attempts by the Obama administration to address climate change. Few, if any, have focused exclusively on the roles of coal producers and electric utilities.

In this context, the analysis here provides new insights into the preferences of business actors in both of these crucial industries. First, by honing in on coal producers and electric utilities, I found evidence showing that business actors in these two industries are not uniformly opposed to regulatory measures to limit emissions from coal. While almost all of the coal industry opposed the WaxmanMarkey bill and the Clean Power Plan, the utility industry did not. Instead, electric utilities supported or opposed the regulatory initiatives, or hedged their position. These positions closely correlated with their generation portfolios. Consistent with recent work on firms' preferences in global environmental politics, hedging strategies appear to be especially prevalent in the utility industry (Meckling 2015).

Second, this article identifies implications for policy-makers and activists, who could potentially exploit industry divisions for political gain. In doing so, the argument builds on recent literature that has explored the pathways to building winning green coalitions that will be necessary to overcome the resistance from incumbent fossil fuel industries. For example, some electric utilities could prove useful allies to governments attempting to regulate emissions, not only in the coal industry, but also across the energy sector. Further, given that the US coal industry is in structural decline, as will be discussed, coal producers will be in a much weaker position to resist government regulation than electric utilities.

This article proceeds as follows. The next section introduces the theory on firms' preferences and describes the sources of data, and the section after that provides an overview of the coal and utility industries. The remainder of the discussion examines firms' preferences in both of these industries in response to attempts to introduce an emissions trading scheme in the president's first term, and pollution standards for power plants in his second term. The final section considers the implications for policy-makers and activists. 


\section{Understanding Business Preferences in Global Environmental Politics}

Although corporate actors, or business actors, are not new to global environmental politics, it is important to be clear about what the terms mean (Clapp and Meckling 2013; Falkner 2008; Meckling 2015; Newell 2005; Tienhaara et al. 2012). Among nonstate actors, a distinction is generally made between for-profit actors and nonprofit actors. In essence, this is a distinction based on motivations. Corporate actors are for-profit entities and are primarily motivated by instrumental goals, normally the pursuit of profit for their owners or shareholders. Nonprofit actors, on the other hand, such as environmental NGOs, are not primarily motivated by profit, and typically lay claim to a common good. It goes without saying that such distinctions are never perfect, and some scholars have challenged this distinction (Sell and Prakash 2004). For example, some industry associations are strictly speaking nonprofit, even though their members are corporate actors, and many corporate actors also lay claim to a common good.

So how are preferences determined? Broadly, firms' preferences are considered to be determined by two factors: interests and institutions (Falkner 2008). First, in regulatory contests like those examined here, firms' preferences will be determined by the distributional effect of the policy. Environmental regulations will have different costs and benefits for different industries, and for different firms within the same industry (Keohane et al. 1998). In general, firms tend to support regulations when they benefit from them, and oppose regulations when they do not. However, two firms may both stand to lose from the implementation of a regulation, but one firm might incur lower costs than a competitor, granting it relative gains.

However, preferences also reflect the institutional environment in which firms operate. In other words, their economic interests are filtered through the institutions and networks to which they belong (Hall and Thelen 2009; Layzer 2012; Woll 2008). Institutional factors are likely to be especially important when there is a high level of uncertainty about the distributive impact of a regulation or when the absolute and relative gains are very similar (Levy and Kolk 2002, 282). Research on corporate behavior suggests that a number of institutional factors can explain variance in corporate preferences. The home country of a corporation and the associated political, economic, and cultural contexts can lead to divergent preferences. For example, the adversarial legal system in the US has often led corporations to take more antagonistic positions toward regulations than are taken in Europe (Falkner 2008, 36; Kagan, 2007; Woll 2012). Likewise, the unique histories of different corporations can also lead to different preferences. For example, businesses that have experienced a history of losses with a particular technology are likely to institutionalize a negative view toward the future prospects of such technologies (Levy and Kolk 2002, 208-281).

Further, business preferences are not fixed, but can vary over time in the context of the policy cycle and the institutional environment (Downie 2014; Vogel 1989). For instance, in the agenda-setting phase of policy development, 
evidence from studies of environmental politics suggests that affected firms are more likely to pursue a strategy of opposition when regulations first emerge on the agenda, but as the debate matures, opposition is likely to decrease and become fragmented. Over time, a tipping point can be reached at which business tips from opposition to support (Meckling 2015; Vormedal 2012). In addition, policy feedbacks and path dependence can reshape business interests and the balance between those interests, by helping to determine what actions are possible, desirable, and legitimate (Layzer 2012, chap. 2; Stokes 2015, chap. 2).

It is too simple, then, to speak of "business preferences" as though business is a black box, with one set of consistent and coherent preferences. Business, like the state, is not a unitary actor, and preferences will vary across industries and firms. While competition between businesses is what underpins competitive markets, these same business interests will regularly engage in fierce battles over the rules that govern those markets (Tienhaara et al. 2012, 62). For example, business conflicts between national and international firms are common, especially regarding trade policy, just as conflicts also arise between technology leaders and laggards in the same industry, or between companies that operate in different economics sectors but within the same supply chain (Falkner 2008, chap. 2).

A series of hypotheses flow from this discussion: it is expected that corporate actors would support policies that improved their competitive position in the market. It is also to be expected that when the distributive effects of a policy are uniform across an industry, the industry would have a uniform preference. At the same time, if the distributive effects on firms in the same industry are different, then preferences would be anticipated to differ, and intra-industry conflict would occur. For example, as was noted above, in the utility industry emissions standards on power plants impose higher costs on plants that rely on coal than on those that rely on gas. Institutional factors, such as the home country of a corporation, are also expected to be important when there is a high level of uncertainty about the distributive impact of a regulation or when the absolute and relative gains are very similar.

To consider these hypotheses, ten producers were identified in the coal industry, representing 76 percent of total US coal production, and fifteen electric utilities, representing 71 percent of the total market capitalization of investorowned utilities (EEI 2014; EIA 2015, 16). To be selected, a firm did not need to be headquartered in the US, but it did need to have a presence in the US market. Three sources of data were sought with which to determine the preferences of each firm: first, documentation in which a firm states, or is directly reported to have stated, a position on each of the regulatory initiatives, such as a company press release, speech, or newspaper report covering the firm's position; second, documentation from an industry association of which the firm is a member; third, newly conducted interviews with senior executives from a sample of firms within the industry, among both coal producers and electric utilities. The latter were supplemented by interviews with relevant national and state-based industry 
associations. In all, seventy-one interviews were conducted between 2014 and 2015 with corporate actors in the US energy sector. Of these, twenty-three of the respondents directly represented coal producers, electric utilities, and/or relevant industry associations.

\section{Overview of the US Coal and Utility Industries}

The US coal industry is in decline. Coal production, the number of producing mines, productive capacity, and the number of employees at US coal mines are all declining (EIA 2015). The decline of coal is also being felt in the utility industry. Over the last two decades, coal's share of electricity generation has fallen from more than half in 1990, to around a third today (IEA 2013, 159). And record numbers of coal-fired power plants are now retiring (BNEF 2015, 5).

However, the US still holds the world's largest coal reserves, and after China, it is the largest coal consumer in the world. Coal remains the number one single source of electricity production in the US (IEA 2014). Given the global importance of US efforts to reduce greenhouse gas emissions, the Obama administration's attempts to regulate the coal sector will have, and are already having, a ripple effect around the world, as other nations grapple with the same task (IEA 2014).

So who are the corporate actors? According to the Energy Information Administration (EIA), in the coal industry the top ten producers are Peabody Energy, Arch Coal, Alpha Natural Resources, Cloud Peak Energy, Rio Tinto, Murray Energy, Westmoreland Coal, Alliance Resource Operating Partners, Energy Future Holdings, and NACCO Industries. Peabody is the world's largest coal company, producing around 183 million short tons of coal in 2013 (EIA 2015, 16). Most of its coal assets are thermal coal, which means it is acutely exposed to changes in electricity generation (Witter 2015, 26). In the US, the majority of coal mined is located in West Virginia, Kentucky, and Wyoming. Historically, the American Coal Council (ACC) and the National Mining Association (NMA) have been the principal advocates for coal producers.

Alongside the coal industry is the utility industry. The utilities sector in the US is dominated by investor-owned utilities, which comprise about 70 percent of the sector. In terms of market value, the top fifteen investor-owned electric utilities are Duke Energy, NextERA Energy, Dominion Resources, Southern Company, Exelon, American Electric Power, Sempra Energy, PG\&E, PPL Corporation, Edison International, Public Service Enterprise Group, Consolidated Edison, Xcel Energy, Northeast Utilities, and FirstEnergy. ${ }^{1}$ Although not all utilities use coal, many do, given that more than half of the coal produced in the US is used to provide electricity, with the figure rising to 90 percent for thermal coal (Witter 2015, 4). Among the top fifteen utilities, coal use varies considerably as a percentage of their generation portfolios (Table 1). The principal industry

1. Exelon is currently attempting to merge with Pepco, which would likely make it the largest utility in the US (Medici 2016). 
Table 1

Percentages of Coal Generation by Utilities

\begin{tabular}{lll}
\hline Utility & 2015 & 2009 \\
\hline Duke Energy & $42^{*}$ & 62 \\
NextEra Energy & 0 & $0^{\wedge}$ \\
Dominion & 26 & $30^{\wedge}$ \\
Southern Company & 34 & 68 \\
Exelon & $0^{\wedge}$ & less than 25 \\
American Electric Power & $60^{* \wedge}$ & $66^{\wedge}$ \\
Sempra Energy (SDG\&E) & 0 & 4 \\
PG\&E & 0 & 1 \\
PPL Corporation & - & - \\
Edison International & $8^{* \wedge}$ & $8^{\wedge}$ \\
Public Service Enterprise Group & 21 & $15^{\wedge}$ \\
Consolidated Edison & $l e s s$ than 30 & less than 30 \\
Xcel Energy & 46 & 50 \\
Northeast Utilities/ Eversource & - & - \\
First Energy Corporation & $56^{\wedge}$ & more than 60 \\
\hline
\end{tabular}

*2014 data.

$\wedge$ Percentage is generation capacity. Sources: Annual reports, U.S. Securities and Exchange Commission filings, and direct correspondence with utilities. Due to variations across these sources, the figures are estimates only.

association for the investor-owned utilities is the Edison Electric Institute (EEI), which has over 250 members operating across the US (EEI 2014).

\section{Case 1: The Waxman-Markey Bill}

The inauguration of President Obama in January 2009 came with high hopes of federal action on climate change. Within six months of taking office, the United States House of Representatives had passed the first ever federal legislation to mitigate climate change. The American Clean Energy and Security Act of 2009, the so-called Waxman-Markey bill, named after its cosponsors, aimed to put in place a nationwide emissions trading scheme, or in American vernacular, "a cap and trade" scheme (US Congress 2009). However, the legislation never made it through the Senate, and 12 months later, after a bitter fight, the high hopes had been dashed, and cap and trade was dead. ${ }^{2}$

2. Hulse, Carl, and David M. Herszenhorn. Democrats Call Off Climate Bill Effort. The New York Times, July 22, 2010. 
Corporate actors had been central to the fight, none more so than the coal and utilities industries, which were directly impacted by the legislation. The Waxman-Markey bill comprised a series of measures, such as renewable energy and energy efficiency standards, designed to reduce US greenhouse gas emissions by 17 percent below 2005 levels by 2020. The centerpiece of the legislation was an emissions trading scheme, which set a cap on greenhouse gas emissions from covered sectors, such as the electricity sector, and allowed these firms to trade the emissions permits. Electric utilities would be allocated the vast majority of their permits for free, with approximately 20 percent of the scheme's permits being auctioned (Pew Center on Global Climate Change 2009). While estimates varied, the EPA projected that the price of permits would be relatively modest, at around \$15 per ton in 2015 (EPA 2009). The bill also provided financial incentives and federal funding for clean coal technology (Center for Climate and Energy Solutions 2010).

\section{Preferences}

In the contest over the Waxman-Markey bill, coal producers and utilities formed a preference either to support or oppose the bill. As outlined, we would expect firms to adopt positions that would improve their competitive position in the market. Hence, we would expect that in the coal industry, firms would oppose the bill because it would increase the cost of their product. However, in the utility industry we would expect the preferences of electric utilities to vary according to the generation portfolios of the individual utilities. Where this occurs, intraindustry conflict would be expected.

Turning first to the coal industry, the top ten coal producers, which represent around 76 percent of total US coal production, were almost uniformly opposed to the Waxman-Markey bill, with Rio Tinto the principal exception. ${ }^{3}$ Although the projected cost for coal was arguably modest-at around $\$ 15$ per ton, according to EPA estimates-all coal producers stood to lose (EPA 2009). In addition, given that most coal corporations, such as Peabody Energy and Arch Coal, rely on coal for almost 100 percent of their revenues, losses across the industry were relatively even, and these firms did not stand to make relative gains compared to their competitors. The institutional environment in which coal corporations operated reinforced this position. The coal industry has a long history of opposing environmental regulations, especially climate initiatives, and many of their industry associations, such as the NMA and the ACC, derided the need for action on climate change, and saw the Waxman-Markey bill as part of an ideological crusade, a "war on coal." ${ }^{4}$ Further, given the uniformity in

3. Among the top ten coal producers, six were opposed, one supported, and three were classified as uncertain, though on the basis of industry association membership, it seems likely that they were opposed. They latter three were Alliance Resource Operating Partners, Energy Future Holdings, and NACCO Industries.

4. Interviews 5 and 51, coal lobbyists, 2014. 
preferences, as expected there were no signs of intra-industry conflict, and the ACC and NMA campaigned against the legislation. ${ }^{5}$

The exception was Rio Tinto. There are two potential explanations: first, Rio Tinto was less exposed to coal than were the other coal corporations. Coal contributed just 8 percent to Rio Tinto's total global revenues, as compared to more than 90 percent for most coal corporations (Rio Tinto 2010, 5). Second, and arguably more importantly, were institutional factors. Research on variance in corporate preferences indicates that the home country of a corporation and the associated political, economic, and cultural context can lead to divergent preferences (Falkner 2008; Levy and Kolk 2002). This appears to have been the case with Rio Tinto, which is headquartered in the United Kingdom. Unlike its counterparts headquartered in the US, Rio Tinto was more familiar with emissions trading. It had been exposed to similar debates in Europe and Australia, and had come to support a market-based mechanism in these jurisdictions prior to the contest over the Waxman-Markey bill (Rio Tinto 2009).

The utility industry was a different story. Among the top fifteen electric utilities, which represent 71 percent of the total market capitalization, there was almost complete support for the ultimate Waxman-Markey bill. ${ }^{6}$ However, a closer interrogation of the data indicates that in reality the utilities can be categorized into three broad groups, which closely correlated to their generation portfolios. First, utilities that maintained diverse generation portfolios, which included less than a third coal and often had growing renewable-energy portfolios, openly supported the bill from the outset because of the relative gains they were likely to make (Point Carbon 2009). For example, NextEra Energy, PG\&E, and Edison International, which supported the bill, all had significant renewableenergy portfolios. This is consistent with recent research on utilities and the Waxman-Markey bill, which suggests that utilities with high renewable-energy generation, for example, lobbied to support the bill because of potential gains (Kim et al. 2016).

Second, utilities that generated more than a third of their electricity from coal, and often as much as two-thirds, hedged their position. With strong pressure for regulatory action on climate change under President Obama, they worked to shape the legislation to minimize the compliance costs. This meant that at some points they opposed the legislation, and at others they supported it, as they worked to influence the detail of the bill. Duke Energy is a case in point. Despite relying on coal for almost two-thirds of its generation capacity, Duke Energy supported the Waxman-Markey bill. As the CEO of Duke Energy, Jim Rogers put it, "if you're not at the table, you're going to be on the menu."

5. Interviews 5 and 51, coal lobbyists, 2014.

6. Among the top fifteen electric utilities, eleven supported, one opposed, and three were classified as uncertain because of conflicting or inconclusive evidence. The latter three were Xcel Energy, Northeast Utilities, and FirstEnergy.

7. Wilkie, Christina. Jim Rogers, Duke Energy CEO, Stands to Gain from DNC. Huffington Post, September 7, 2012. 
As a leading member of USCAP, the coalition of business actors and NGOs that had driven the emissions trading debate, Duke Energy played a key role in shaping the bill to ensure that 90 percent of emissions from the utility sector would be covered via free permits (Pooley 2010, 318-319). American Electric Power was a similar case. It also relied on coal for close to two-thirds of its generation capacity. While it ultimately decided to support the Waxman-Markey bill, interviews with utilities suggested that this was only after they became convinced that legislation was inevitable. ${ }^{8}$ As the CEO of American Electric Power, Mike Morris, stated:

American Electric Power supports the American Clean Energy and Security Act. No legislation is perfect-particularly one that seeks to overhaul the way our nation uses energy - but we believe this climate bill will work and it represents the best of the available options. (American Electric Power 2009)

As the interviews revealed, "the best of the available options" meant supporting the bill because "when Obama and the Democrats controlled both houses it was clear that there was going to be legislation and legislation could succeed." ${ }^{9}$

Further, these utilities were part of an institutional environment that was not as hostile to climate initiatives as the coal industry. As noted, Duke Energy was a leading member of USCAP, and some CEOs, including Jim Rogers, appear to have been "bitten by the climate bug," and were of the view that climate change was an issue that required action and that emissions trading provided the greatest flexibility for utilities to limit their emissions. ${ }^{10}$

Third, some utilities that generated more than a third of their electricity from coal decided to oppose the Waxman-Markey bill outright, rather than hedge their position. Among the top fifteen investor-owned utilities, Southern Company was the only utility to adopt this position, with coal representing 68 percent of its generation capacity in 2009. Southern Company opposed the bill, hiring sixty-three lobbyists-far more than any other utility (Lavelle and Donald 2009). The interview data suggest that this utility was especially close to the coal industry and strongly supported its position against the bill. In addition, unlike Duke Energy, it was not a member of USCAP, which was pushing emissions trading. ${ }^{11}$

Finally, given the uneven distributional impact of the Waxman-Markey bill on the electric utility industry, intra-industry conflict did occur. While most of the largest electric utilities ultimately supported the bill, as did the leading industry association the EEI, Southern Company spent $\$ 2.7$ million lobbying against the bill. Other EEI members, notably the Midwest Climate Coalition, broke ranks entirely and campaigned against the EEI (Mildenberger 2013). These

\footnotetext{
8. Interview 6, utility executive, 2014.

9. Interview 6 and 46, utility executives, 2014.

10. Pooley, Eric. McCain's Gift to the Green Movement. Time, May 14, 2008.

11. Interviews 46 and 51, utility executive and coal lobbyist, 2014.
} 
divisions spilled out across the business community. For instance, some utilities, such as Exelon and PG\&E, that backed the bill abandoned their membership in broader industry associations-notably the National Association of Manufacturers, because of its position against emissions trading. ${ }^{12}$

\section{Case 2: The Clean Power Plan}

In the wake of the failure to legislate an emissions trading scheme, President Obama turned to regulation. In June 2013, he directed the EPA to establish carbon pollution standards for the power sector, with the aim to reduce emissions from power plants by 30 percent from 2005 levels by 2030 (The White House 2013b). The announcement was the central part of the President's Climate Action Plan, which comprised a series of initiatives to ensure that the US would meet its commitment to reduce greenhouse gas emissions by 17 percent below 2005 levels by 2020 (The White House 2013a). The decision to turn to regulation after the failure of the Waxman-Markey bill was made possible by a succession of rulings by the Supreme Court, which confirmed the EPA's power to regulate greenhouse gases.

The President instructed the EPA to establish carbon pollution standards under the Clean Air Act for both new and existing power plants. Under the Act (section 111b), the EPA was to establish a federal standard based on the best demonstrated technology for new or modified power plants, which as we will see in effect required new power plants to operate with clean coal technology. However, for existing power plants (section 111d), which are the largest source of carbon dioxide emissions, the EPA was to set emission guidelines with states to design and implement individual implementation plans that were consistent with the EPA's guidelines. In doing so, the EPA provided significant flexibility for states to reduce emissions from power plants using four "building blocks," including increasing the efficiency of plants or relying on natural gas. Where states failed to submit a satisfactory plan, the EPA could design and enforce a federal plan to reduce emissions from existing power plants in that state. Following the release of the proposed rules in 2014, the plan was finalized in August 2015 and is due to be implemented in 2016 (EPA 2015). However, the administration has already agreed to delay the submission of state implementation plans until 2018, and they are almost certain to face further legal challenges. ${ }^{13}$

12. Interviews 35 and 14, business lobbyists, 2015; Morford, Stacy. Exelon Latest to Leave US Chamber of Commerce; Is Nike Next? InsideClimate News, September 28, 2009.

13. Davenport, Coral. Later Deadline Expected on Obama's Climate Plan. The New York Times, July 28, 2015. 


\section{Preferences}

Much like the Waxman-Markey bill, we would expect that a firm's preference to support or oppose the Clean Power Plan would reflect their competitive position in the market and the institutional environment in which they operated. Accordingly, we would expect that coal corporations would oppose the regulations and that the preferences of utilities would vary largely on the basis of the amount of coal in their generation portfolio. We would also anticipate that when preferences within an industry are not uniform, intra-industry conflict would emerge.

Turning first to the coal industry, each of the top ten coal producers opposed Obama's Clean Power Plan, aside from Rio Tinto. ${ }^{14}$ This is no surprise, given that coal producers uniformly stood to lose. Coal corporations viewed the Clean Power Plan as an "existential threat" to the industry. ${ }^{15}$ According to interviews in the industry, the Clean Power Plan would put coal in a much less competitive position than the Waxman-Markey bill, which provided greater flexibility. More importantly, by in effect requiring all new coal-fired power plants to be equipped with clean coal technology, a technology that those in the industry freely admitted did not yet exist on a commercial scale, the proposed regulations had a chilling effect by reinforcing the view in the investment community that the coal industry is a high-risk investment (Downie and Drahos, 2015). ${ }^{16}$ The institutional environment in which these coal firms operated strengthened this position. Many coal corporations continued to deride the need for action on climate change. For some, such as Murray Energy, climate change was simply a hoax. ${ }^{17}$ With the leading coal industry associations, namely the ACC and the NMA, opposed to the Clean Power Plan, there were no signs of intra-industry conflict.

Rio Tinto was again the principal exception. The reasons are likely the same. First, Rio Tinto was a much more diversified energy corporation, with less than 10 percent of its global revenues deriving from coal. Second, as a Europebased corporation, it operated in a different institutional context, and like many European corporations, it continued to take an active role in discussions of climate change. For example, in 2015, in the lead-up to the international climate negotiations in Paris, Rio Tinto signed the American Business Act on Climate Pledge to demonstrate its support for action on climate change (The White House 2015).

14. Among the top ten coal producers, seven opposed, one supported, and two were classified as uncertain, though based on industry association memberships, it seems likely that they were opposed. The latter two were Energy Future Holdings and NACCO Industries.

15. Interview 35, business lobbyist, 2015.

16. Interviews 46, 21, and 51, utility executives and coal lobbyist, 2014.

17. Jett, Jennifer. Man Standing: Bob Murray and the War on Coal. West Virginia Executive, May 30, 2014. 
In contrast to the coal industry, the preferences of utilities were more nuanced. Although utilities appear to support the Clean Power Plan, the interview data indicate that, as with the Waxman-Markey bill, their preferences again can be categorized into three broad groups. ${ }^{18}$ First, utilities that had less than 30 percent coal in their generation mix and growing renewable-energy portfolios, such as NextEra Energy and Exelon, supported the proposed regulationsl, because in many cases they stood to make relative gains. Others-for example, PG\&E, which had no coal and 35 percent renewables in its generation mixwere "already looking well beyond" the Clean Power Plan. ${ }^{19}$

Second, utilities with generation portfolios that included more than 30 percent coal continued to hedge their position. This was manifested in two ways-namely, working to shape the regulations and indirectly opposing them. First, Duke Energy's position appears to have reflected the view that in the face of strong regulatory pressure, it is better to try and shape the regulations than to outright oppose them. This was the same approach that it had taken in the contest over the Waxman-Markey bill, despite the fact that Lynn Wood had replaced Jim Rogers as CEO of Duke Energy (Duke Energy 2015). The position of Xcel Energy was the same. Despite coal comprising 46 percent of its generation capacity, it, too, sought to shape the regulations should they be implemented, so that it could gain from its renewable-energy portfolio, which had grown to almost 20 percent by 2014 (Dunbar 2014). ${ }^{20}$ Second, while both Duke Energy and Xcel Energy publicly supported the regulations, there is evidence to suggest that they indirectly opposed the Clean Power Plan. For example, both corporations did not dissociate from groups that were fighting the regulations in court or were working with state governments to do so, such as the Utility Air Regulatory Group (Walke 2012). Indeed, both had funded law firms that worked in the courts to undermine EPA regulations, and they were by no means the only ones. For example, American Electric Power continued to do the same (Kasper 2015). ${ }^{21}$ As one insider explained, the "the vast majority [of utilities] are not suing the EPA, but that does not mean they are not pushing state governments to do so on their behalf." 22

Third, among the utilities that generated more than a third of their electricity from coal and stood to lose from the Clean Power Plan, Southern Company was again the only utility to oppose the regulations outright. Much as it did in the case of the Waxman-Markey bill, Southern Company does not appear to have tried to hedge its position; rather, it opposed the regulations, and did so

18. Among the top fifteen electric utilities, thirteen supported, one opposed, and one (PPL Corporation) was classified as uncertain because of conflicting or inconclusive evidence.

19. Interview 38, utility executive, 2015.

20. Dunbar, Elizabeth, Minn. Could Have to Reduce Carbon by $40 \%$ Under New Rule. MPR News, June 2, 2014.

21. Interview 6, utility executive, 2014.

22. Interview 41, industry association, 2015. 
vociferously. In comments submitted to the EPA, Southern Company claimed that:

The proposed Clean Power Plan extends beyond the EPA's authority under the Clean Air Act, is unworkable, and would increase electricity prices to customers while jeopardizing reliability. This will result in a complete deconstruction of the nation's electric sector and negatively impact America's energy security. (EPA 2014)

While it remains unclear precisely why Southern Company took such a critical position toward the regulations, rather than hedging its position, institutional factors may be at play. As has been discussed, previous research has indicated that the unique history of a corporation can explain variance in corporate preferences. The interview data suggest that Southern Company was closely tied to the coal industry, and importantly, it had also made a recent decision to invest in a clean coal demonstration project in conjunction with the Department of Energy-the so-called Kemper County project, a 582-MW integrated gasification combined cycle plant, which aims to sequester 50 percent of its $\mathrm{CO}_{2}$ (Downie and Drahos, 2015). As one utility executive pointed out, this represented a significant "investment in the future of coal." ${ }^{23}$

Finally, because of the uneven distributive impact of the Clean Power Plan, some intra-industry conflict could be expected. What is interesting in this case is that, at least initially, there appears to have been a general disposition across the utility industry to oppose the regulations. According to interviews, there was a consensus view that the EPA rules in their initial form were simply "unpalatable." ${ }^{24}$ As one utility executive claimed, "the EPA regulations have set a standard that is beyond our best plant ... you cannot build new coal plants." ${ }^{25}$ In part, this may reflect that sections of the business community had come to prefer emissions trading, as proposed in the Waxman-Markey bill, to commandand-control forms of regulation, as proposed by the EPA (Meckling 2011).

Further, it may be the case that the act of hedging works to limit intra-industry divisions and outright conflict. For example, as some utilities tried to shape the rules, the language from executives, including the EEI, softened, and many executives came to support the Clean Power Plan, at least publicly (EEI 2015). As a result, electric utilities did not break away and campaign against the EEI, as they had over the Waxman-Markey bill. ${ }^{26}$ Nevertheless, the wider institutional environment in which utilities participated was strongly opposed to the Clean Power Plan. For example, two of the most prominent business associations, the Chamber of Commerce and the National Association of Manufacturers, led the campaign against the EPA in public and in the courts, and many utilities were prominent members of both these associations. ${ }^{27}$

23. Interviews 46, 51, utility executive and coal lobbyist, 2014.

24. Interview 22, utility executive, 2014.

25. Interview 6, utility executive, 2014.

26. Interviews 22, 6, 46, and 41: utility executives, 2014, and industry association, 2015.

27. Interviews 14 and 35, business lobbyists, 2015. 


\section{Conclusions}

Although very few studies have focused exclusively on the role of business actors in the US coal and electric utility industries, these actors merit attention. To be sure, coal is the largest source of greenhouse gas emissions in the world, and the US still holds the largest coal reserves on the planet. Any government efforts to restrict emissions from coal will not succeed, however, unless they overcome the resistance of the incumbent coal and utility industries, which have generated great wealth from burning coal.

In this context, this article shows that there are divisions among corporate actors in the coal and utility industries, and that those actors are not uniformly opposed to regulatory measures to limit emissions from coal. First, in the coal industry all but one of the top coal producers opposed emissions trading and direct regulation, because of the adverse impact the regulations would have on their competitive position in the energy market. In both cases coal producers stood to lose, given that most corporations relied on coal production for close to 100 percent of their revenues. The exception was Rio Tinto, which was a much more diversified energy corporation headquartered in the UK, not the US. This meant that it operated in a different institutional environment, one generally more supportive of action on climate change.

Second, in the utility industry the data reveal more nuanced positions. Specifically, electric utilities can be categorized into three broad groups that supported, hedged, or opposed the regulatory initiatives. These positions closely correlated to their generation portfolios. Consistent with recent work on firms' preferences in global environmental politics, the most important insight is that hedging strategies are an especially prevalent form of corporate behavior (Meckling 2015). This was manifest in two ways-namely working to shape regulations, especially when they looked likely to succeed, and/or supporting them publicly while indirectly opposing them.

Finally, the uneven distribution of preferences across the utility industry did result in intra-industry conflict, primarily in the contest over the WaxmanMarkey bill. While the leading industry association, the EEI, supported emissions trading, other EEI members broke ranks and campaigned against their industry colleagues. Such divisions were much less apparent in the contest over the Clean Power Plan, in that many utilities that initially opposed the regulations came to support them, at least publicly, as they looked more likely to succeed.

These findings are significant for policy-makers and activists. First, if governments are to successfully implement measures to restrict emissions from coal, they will need to build winning coalitions (Meckling et al. 2015). The evidence presented here shows that there are divisions within the US coal and utility industries, which can be exploited for political gain. One way is for policy-makers to target coal producers that oppose climate regulations in the first instance, given their relatively weak financial position. As was discussed, the US coal industry is in structural decline, with production and revenue falling steadily. 
Several coal corporations are now on the brink of bankruptcy. In August 2015, Alpha Natural Resources, which was the third largest coal corporation in the US, filed for bankruptcy after its share price fell to under $\$ 1$, and Arch Coal followed in 2016. They are not expected to be the last. ${ }^{28}$ Another way is for policy-makers to look for allies among electric utilities. For instance, utilities less reliant on coal, such as those that generate less than a third of their electricity from coal, or that have rising renewable-energy portfolios, could be enlisted to counter the resistance from coal producers. However, policy-makers and activists need to be wary of utilities that hedge their position by publicly supporting regulations while indirectly opposing them, as American Electric Power did.

Second, policy-makers should look to exploit cleavages within the utility industry. If policy-makers consistently target low-hanging fruit, they may find that once the fruit has been picked, resistance from incumbent industries will not have shifted, and future, more stringent climate regulations will be equally hard to implement (Kelsey 2014, 6). For instance, renewable portfolio standards that mandate that utilities supply a specific percentage of renewable energy can lead to structural reconfiguration in the utility sector, as utilities invest in renewable generation at the expense of coal-fired generation. Over time, this can lead utilities that were once largely opposed to the regulation of coal to shift their interests to support climate regulations that benefit their investments in cleaner technologies.

Third, in implementing measures to restrict emissions from coal, policymakers should avoid making trade-offs that could result in negative feedbacks. For example, in the contest over the Waxman-Markey bill, the Obama administration agreed to include $\$ 1$ billion in funding to support clean coal. Clean coal had been actively promoted by both industries, including many of the most powerful coal producers and coal-fired utilities, such as Peabody Energy, Southern Company, and American Electric Power. ${ }^{29}$ Although such large public subsidies for clean coal technology may have great potential to reduce emissions, and although they were arguably helpful in garnering support for the bill, they can also work to lock in decades of further coal generation by providing a justification for its ongoing exploitation, which may help explain Southern Company's ongoing opposition to the Clean Power Plan. Policy-makers will need to weigh carefully the trade-offs of such policies, especially in cases in which the technologies have consistently failed to deliver, as is the case with clean coal technology (Downie and Drahos, 2015).

Finally, these findings also suggest avenues for future research. The results should be tested across other industries, such as the oil and gas industry. However, further empirical work will also be needed to examine the relationship between institutional factors and firms' preferences. Commercial interests clearly

28. Miller, John W., and Peg Brickley. Arch Coal Files for Bankruptcy. The Wall Street Journal, January 11, 2016.

29. Interviews 6 and 46, utility executives 2014 . 
drive corporate behavior, but the home country of a corporation or its unique history, for example, also play roles. A better understanding of such institutional factors, and of others not examined here, would provide useful insights into the reasons why some firms develop preferences that seemingly do not align with their commercial interests.

\section{References}

American Electric Power. 2009. AEP's Position on Climate Legislation Is Clear: A Message from AEP Chairman, President \& CEO Michael G. Morris. Press Release, September 14, 2009. Available at https://grist.files.wordpress.com/2010/09/mikemorriswaxman-markeystatement.pdf, accessed June 9, 2015.

BNEF. 2015. Medium-Term Outlook for US Power. Bloomberg New Energy Finance White Paper, April 8, 2015, New York. Available at http://about.bnef.com/content/uploads/ sites/4/2015/04/BNEF_2015-02_AMER_US-Power-Fleet-De-Carbonisation-WP.pdf, accessed June 9, 2015.

Center for Climate and Energy Solutions. 2010. In Brief: What the Waxman-Markey Bill Does for Coal. Center for Climate and Energy Solutions. Available at www.c2es. org/docUploads/brief-what-waxman-markey-does-for-coal-may2010.pdf, accessed June 9, 2015.

Clapp, Jennifer, and Jonas Meckling. 2013. Business as a Global Actor. In The Handbook of Global Climate and Environmental Policy, edited by Robert Falkner, 286-303. New York: Wiley. doi:10.1002/9781118326213.ch17.

Downie, Christian. 2014. The Politics of Climate Change Negotiations: Strategies and Variables in Prolonged International Negotiations. Cheltenham, UK: Edward Elgar.

Downie, Christian, and Peter Drahos. 2015. US Institutional Pathways to Clean Coal and Shale Gas: Lessons for China. Climate Policy. doi:10.1080/14693062.2015.1094730.

Duke Energy. 2015. Duke Energy CEO Lynn Good Comments on EPA's Clean Power Plan. News Release, August 3, 2015. Available at https://www.duke-energy.com/news/ releases/2015080301.asp, accessed June 9, 2015.

EEI. 2014. Stock Performance: Q4 2014 Financial Update. Quarterly Report of the U.S. Shareholder-Owned Electric Utility Industry. Edison Electric Institute. Available at http:// www.eei.org/resourcesandmedia/industrydataanalysis/industryfinancialanalysis/ QtrlyFinancialUpdates/Documents/QFU_Stock/2014_Q4_Stock_Performance.pdf.

EEI. 2015. EEI Statement on EPA's Clean Power Plan. Press Release, August 3, 2015. Available at www.eei.org/resourcesandmedia/newsroom/Pages/Press\%20Releases/ EEI\%20Statement\%20on\%20EPA\%E2\%80\%99s\%20Clean\%20Power\%20Plan. aspx, accessed June 9, 2015.

EIA. 2015. Annual Coal Report 2013. Washington, DC: Energy Information Administration.

EPA. 2009. EPA Preliminary Analysis of the Waxman-Markey Discussion Draft. Washington, DC: Environmental Protection Agency. Available at https://www3. epa.gov/climatechange/Downloads/EPAactivities/WM-Analysis.pdf, accessed June 9, 2016.

EPA. 2014. Comments of Southern Company. Available at https://www.regulations.gov/ index.jsp\#!documentDetail;D=EPA-HQ-OAR-2013-0602-22907, accessed June 9, 2016. 
EPA. 2015. Clean Power Plan Final Rule. Washington, DC: Environmental Protection Agency. Available at https://www.gpo.gov/fdsys/pkg/FR-2015-10-23/pdf/201522842.pdf, accessed June 9, 2016.

Falkner, Robert. 2008. Business Power and Conflict in International Environmental Politics. New York: Palgrave Macmillan.

Hall, Peter A., and Kathleen Thelen. 2009. Institutional Change in Varieties of Capitalism. Socio-Economic Review 7: 7-34.

IEA. 2013. World Energy Outlook 2013. Paris: International Energy Agency.

IEA. 2014. World Energy Outlook 2014. Paris: International Energy Agency.

Kagan, Robert A. 2007. Globalization and Legal Change: The "Americanization" of European Law? Regulation and Governance 1: 99-120.

Kasper, Matt. 2015. Corporations Behind the Lawsuit Against the EPA. Energy and Policy Institute. Available at www.energyandpolicy.org/corporations-behind-the-lawsuitagainst-the-epa/, accessed June 9, 2016.

Kelsey, Sarah. 2014. The Green Spiral: Policy-Industry Feedback and the Success of International Environmental Negotiation. PhD Thesis, University of California, Berkeley.

Keohane, Nathaniel, Richard Revesz, and Robert Stavins. 1998. The Choice of Regulatory Instruments in Environmental Policy. Harvard Environmental Law Review 22: 313-367.

Kim, Sung Eun, Johannes Urpelainen, and Joonseok Yang. 2016. Electric Utilities and American Climate Policy: Lobbying by Expected Winners and Losers. Journal of Public Policy 36: 251-275.

Knox-Hayes, Janelle. 2012. Negotiating Climate Legislation: Policy Path Dependence and Coalition Stabilization. Regulation and Governance 6: 545-567.

Lavelle, Marianne, and David Donald. 2009. Southern Company Dominates the Climate Lobbying Scene. The Center for Public Integrity. Available at https://www. publicintegrity.org/2009/07/01/2830/southern-company-dominates-climatelobbying-scene, accessed June 9, 2016.

Layzer, Judith. 2012. Open for Business: Conservatives' Opposition to Environmental Regulation. Cambridge, MA: MIT Press.

Levy, David, and Ans Kolk. 2002. Strategic Responses to Global Climate Change: Conflicting Pressures on Multinationals in the Oil Industry. Business and Politics 4: 275-300.

Meckling, Jonas. 2011. Carbon Coalitions: Business, Climate Politics, and the Rise of Emissions Trading. Cambridge, MA: MIT Press.

Meckling, Jonas. 2015. Oppose, Support, or Hedge? Distributional Effects, Regulatory Pressure, and Business Strategy in Environmental Politics. Global Environmental Politics 15 (2): 19-37. doi:10.1162/GLEP_a_00296.

Meckling, Jonas, Nina Kelsey, Eric Biber, and John Zysman. 2015. Winning Coalitions for Climate Policy. Science 349: 1170-1171.

Medici, Andy. 2016. Here's how much Exelon has spent pursuing its $\$ 6.8$ billion merger with Pepco Washington Business Journal, February 11 2016. Available at: http:// www.bizjournals.com/washington/news/2016/02/11/heres-how-much-exelon-hasspent-pursuing-its-6-8.html, accessed 18 November 2016.

Mildenberger, Matto. 2013. The Politics of Strategic Accommodation: Explaining Business Support for US Climate Policy. Paper presented at the International Conference on Public Policy, Grenoble, France, June 26-28.

Newell, Peter. 2000. Climate for Change: Non-State Actors and the Global Politics of the Greenhouse. Cambridge: Cambridge University Press. 
Newell, Peter. 2005. Business and International Environmental Governance: The State of the Art. In The Business of Global Environmental Governance, edited by David Levy and Peter Newell, 21-45. Cambridge, MA: MIT Press.

Pew Center on Global Climate Change. 2009. At a Glance: American Clean Energy and Security Act of 2009. Available at www.c2es.org/docUploads/Waxman-Markeyshort-summary-revised-June26.pdf, accessed June 9, 2016.

Point Carbon. 2009. Carbon Exposure: Winners and Losers in a US Carbon Market. Point Carbon Research, Carbon Market Analyst North America, November 2, 2009. Available at http://graphics8.nytimes.com/images/blogs/greeninc/carbonexposure.pdf, accessed June 9, 2016.

Pooley, Eric. 2010. The Climate War. New York: HarperCollins.

Rio Tinto. 2009. Proposed Emissions Trading Legislation in Australia, October 2009. Available at www.riotinto.com/ourcommitment/features-2932_3267.aspx, accessed June 9, 2016.

Rio Tinto. 2010. Annual Report. Available at www.riotinto.com/documents/Investors/ RioTinto_Annual_report_2010.pdf, accessed June 9, 2016.

Sell, Susan K., and Aseen Prakash. 2004. Using Ideas Strategically: The Contest Between Business and NGO Networks in Intellectual Property Rights. International Studies Quarterly 48: 143-175.

Skjærseth, Jon Birger, Guri Bang, and Miranda A. Schreurs. 2013. Explaining Growing Climate Policy Differences Between the European Union and the United States. Global Environmental Politics 13 (4): 61-80. doi:10.1162/GLEP_a_00198.

Stokes, Leah. 2015. Power Politics: Renewable Energy Policy Change in US States. PhD thesis, MIT, Cambridge, MA.

Tienhaara, Kyla, Amandine Orsini, and Robert Falkner. 2012. Global Corporations. In Global Environmental Governance Reconsidered, edited by Frank Biermann and Philipp Pattberg, 45-67. Cambridge, MA: MIT Press.

US Congress. 2009. H.R.2454: American Clean Energy and Security Act of 2009. Available at https://www.congress.gov/bill/111th-congress/house-bill/2454, accessed February 24, 2016.

Vogel, David. 1989. Fluctuating Fortunes. New York: Basic Books.

Vormedal, Irja. 2012. States and Markets in Global Environmental Governance: The Role of Tipping Points in International Regime Formation. European Journal of International Relations 18: 251-275.

Walke, John. 2012. Is Your Power Company Fighting in Court Against Safeguards from Mercury and Toxic Air Pollution? Natural Resources Defense Council. Available at https://www.nrdc.org/experts/john-walke/your-power-company-fighting-courtagainst-safeguards-mercury-and-toxic-air, accessed June 9, 2016.

The White House. 2013a. The President's Climate Action Plan. Washington, DC: Executive Office of the President. Available at https://www.whitehouse.gov/sites/default/ files/image/president27sclimateactionplan.pdf, accessed June 9, 2016.

The White House. 2013b. Presidential Memorandum: Power Sector Carbon Pollution Standards. Press Release, June 25, 2013. Available at https://www.whitehouse. gov/the-press-office/2013/06/25/presidential-memorandum-power-sector-carbonpollution-standards, accessed June 9, 2016.

The White House. 2015. White House Announces Additional Commitments to the American Business Act on Climate Pledge. Press Release, November 30, 2015. 
Available at https://www.whitehouse.gov/the-press-office/2015/11/30/whitehouse-announces-additional-commitments-american-business-act, accessed June 9, 2016.

Witter, David. 2015. IBIS World Industry Report: Coal Mining in the US. Melbourne: IBIS World. On file with author.

Woll, Cornelia. 2008. Firm Interests: How Governments Shape Business Lobbying on Global Trade. Ithaca, NY: Cornell University Press.

Woll, Cornelia. 2012. The Brash and the Soft-Spoken: Lobbying Styles in a Transatlantic Comparison. Interest Groups and Advocacy 1 (2): 193-214. 